University of Nebraska - Lincoln

DigitalCommons@University of Nebraska - Lincoln

Faculty Publications, Department of Psychology

Psychology, Department of

2007

\title{
Will They Tell? Weapons Reporting by Middle-School Youth
}

\author{
Eve M. Brank \\ University of Nebraska-Lincoln, ebrank2@unl.edu \\ Jennifer L. Woolard \\ Georgetown University \\ Veda E. Brown \\ Prairie View A\&M University \\ Mark Fondacaro \\ City University of New York \\ Jennifer L. Luescher \\ Bridegwater State Hospital
}

See next page for additional authors

Follow this and additional works at: https://digitalcommons.unl.edu/psychfacpub

Part of the Psychiatry and Psychology Commons

Brank, Eve M.; Woolard, Jennifer L.; Brown, Veda E.; Fondacaro, Mark; Luescher, Jennifer L.; Chinn, Ramona G.; and Miller, Scott A., "Will They Tell? Weapons Reporting by Middle-School Youth" (2007). Faculty Publications, Department of Psychology. 578.

https://digitalcommons.unl.edu/psychfacpub/578

This Article is brought to you for free and open access by the Psychology, Department of at DigitalCommons@University of Nebraska - Lincoln. It has been accepted for inclusion in Faculty Publications, Department of Psychology by an authorized administrator of DigitalCommons@University of Nebraska - Lincoln. 


\section{Authors}

Eve M. Brank, Jennifer L. Woolard, Veda E. Brown, Mark Fondacaro, Jennifer L. Luescher, Ramona G. Chinn, and Scott A. Miller 
Published in Youth Violence and Juvenile Justice (April 2007) 5(2): 125-146. Copyright 2007, Sage. DOI: 10.1177/1541204006296171. http://yvj.sagepub.com. Used by permission.

\title{
Will They Tell? Weapons Reporting by Middle-School Youth
}

\author{
Eve M. Brank, University of Florida (2009-: University of Nebraska-Lincoln) \\ Jennifer L. Woolard, Georgetown University \\ Veda E. Brown, Prairie View A\&M University \\ Mark Fondacaro, City University of New York \\ Jennifer L. Luescher, Bridegwater State Hospital \\ Ramona G. Chinn, Hawaii School of Nursing \\ Scott A. Miller, University of Florida
}

\begin{abstract}
Adding to the body of research that describes students who will bring weapons to school, the current research examined middle-school students' willingness to report when they know someone has a weapon at school. The sample included 1,957 sixth, seventh, and eighth graders from 27 schools in five states. Overall, a majority of students indicated that they would be willing to report; however, there were significant effects for the conditions of reporting (such as anonymity) and effects for some demographic characteristics. Furthermore, students who perceived adult or parental involvement in their lives were more willing to report. In contrast, students with delinquent involvement (self or peers) were significantly less likely to report the presence of weapons.
\end{abstract}

Keywords: Adults; Juveniles; Parents; Peers; Weapons.

School violence incidents have led to metal detectors and police officers becoming a familiar sight in public schools (Bauer, 2003). For at least the past decade, students and parents all over the United States have been on a heightened sense of alert. In fact, $71 \%$ of respondents to a phone survey thought that school shootings could happen in their community (Sullivan, 2002). Media accounts likely compound this fear with stories such as Celia McGinty, an Idaho teenager who during an online chat found herself reading threats of school violence from a student halfway across the country ("Police, Teen Foils," 2004). Andrew Osantowski, age 17 years, told McGinty that he was planning a large-scale violent revenge on his school (Manolatos \& Cardenas, 2004). McGinty reported the threats to her

Authors' Note: This research was supported by a grant from the U.S. Department of Education: Fund for the Improvement of Education Program PR/Award Number R215U010016. We would like to acknowledge Steven Boggs, William Cliett, Imicuk Loyuk, Mel Lucas, Anca Mirsu-Paun, and Stephen Smith for their work on this project. Preliminary findings from the research were presented at the 2005 annual meeting of the American Psychology and Law Society, La Jolla, CA, and a final grant report on the study was provided to the U.S. Department of Education, December, 2003. Correspondence should be addressed to Eve M. Brank, Department of Psychology, University of Nebraska-Lincoln, Lincoln, Nebraska; E-mail: ebrank2@unl.edu. 
parents, who in turn alerted the police. Law enforcement raids of Osantowski's house confirmed his online discussions by revealing weapons and bomb-making supplies (Manolatos \& Cardenas, 2004).

Clearly, there is much juveniles never tell adults, authorities, or their parents. What was it that made McGinty report this boy she had never met? Was there something about the way Osantowski discussed his plans or was there something about McGinty that would have persuaded her to tell no matter the situation? We have anecdotal evidence like the McGinty story that some students will report; however, we have little systematic information about student response to suspicions about, or concrete evidence regarding, other students' plans for violence and/or weapons use at school.

In the wake of school shootings in the 1990s, schools, policy makers, and law enforcement officials searched for effective responses to identify threats. Potential strategies included creating a profile of the school shooter, embracing the use of technology (e.g., metal detectors), and gathering information from collateral sources. Because school shootings are such a low base-rate phenomenon, efforts to create profiles or predictive models suffer from high false-positive and false-negative rates. Yet even without sophisticated profiles, avoiding these incidents may still be possible because postincident evidence suggests that warning signs are commonly given by school shooters. For instance, the two Columbine shooters who killed 12 students, a teacher, and themselves gave warning signs through their Internet pages, their school assignments, and the possessions in their bedrooms (Crittenden, 1999). Although much of the postincident attention focused on the shooters' parents (Glaberson, 1999; Olinger \& Lowe, 1999), some questioned how much their classmates might have known and if they did, why they were unwilling to notify school officials or other adults about the boys' plans (Brooke, 1999). The current research examines fellow students, and their willingness to report weapons, as a potential resource for preventing weapons in schools.

\section{The Fear and Reality of Weapons in Schools}

The problem of weapons in schools is still quite prominent in the public mind (Sullivan, 2002). Approximately $6 \%$ of high school students participating in the 2003 Youth Risk Behavior Survey reported carrying a weapon on school property in the past 30 days, down from 12\% in 1993 (Bauer, 2003; DeVoe et al., 2004). In addition, most accounts indicate that the overall rate of youthful offending in and out of schools has been declining over the past 10 years (DeVoe et al., 2004). Nonetheless, recent research suggests that students believe that many of their fellow classmates are bringing guns to school (Bailey, Flewelling, \& Rosenbaum, 1997; Martin, Sadowski, Cotton, \& McCarraher, 1996) at a higher rate than is actually occurring (May, 1999), and there is a considerable fear as a result. A 1998 National League of Cities survey of 700 localities revealed a widespread view that school and youth violence were critical problems.

\section{Characteristics of Those Students Who Bring Weapons to School}

Enduring concerns about weapons in schools have led many researchers to focus their attention on the kind of student who would bring a weapon on school grounds. Limited primarily to descriptive statistics, this line of research indicates that youth who report carrying weapons share common characteristics that are often not specific or unique to weapons 
carrying. Across several large-scale national and state studies, risk factors for carrying weapons often fall into the following categories: demographic factors, problem behaviors, victimization and fear and/or safety issues, social support and engagement, and peer influences (including perceptions of peer weapons use). A few studies also examine contextual factors such as neighborhood and school characteristics, including social capital, structural features (e.g., socioeconomic status [SES] and race and/or ethnicity distributions), and social climate. Although methodological variability exists in sampling, measurement, and analytic techniques, several important findings emerge across these studies and are examined in the sections that follow.

Students who report carrying weapons to school are more likely to engage in other problem behaviors, and male students report bringing weapons to school at a higher frequency than female students (DeVoe et al., 2004; May, 1999). Students who report carrying weapons to school also report lower perceived social support than their peers who do not report carrying weapons to school (Malecki \& Demaray, 2003; May, 1999). It is not surprising to note that having peers who carry weapons and having a criminal lifestyle are predictive of carrying weapons (Rountree, 2000). Similar to fighting and aggression, weapon carrying is negatively related to family variables such as parental monitoring (Orpinas, Murray, \& Kelder, 1999) and close parental relationships (Bailey et al., 1997) but positively related to substance abuse of the parents (Corvo \& Williams, 2000) and being in a single-parent home (Forrest, Zychowski, Stuhldreher, \& Ryan, 2000). Weapon carrying is also significantly related to a belief that other students are bringing weapons to school (Bailey et al., 1997; Martin et al., 1996). School-level characteristics, such as SES (as measured by the proportion of students eligible for free lunches), can contribute to the likelihood of a student bringing a weapon to school (Wilcox \& Clayton, 2001). In general, carrying a weapon to school is not the student's only illegal behavior; students who carry weapons are usually involved in other deviant behaviors or have other known risk factors (Bailey et al., 1997; Estell, Farmer, Cairns, \& Clemmer, 2003; Malek, Chang, \& Davis, 1998).

The high-profile cases, the fear of more such cases, and the type of students who bring weapons to school have contributed to the warranting of serious consequences by school and public officials for students who bring weapons to school. For example, a Florida statute makes it a felony to bring a weapon onto a school campus (Possessing or Discharging Weapons or Firearms at a School-Sponsored Event, 2004). In response, many schools have taken a zero-tolerance approach to weapons (Juvonen, 2001; Savastana, 2003) or a school-wide team approach with the collaboration of faculty and law enforcement (San Diego City Schools, 2004). Many schools have policies that include automatic suspensions or expulsions when weapons are brought on campus (Gottfredson \& Gottfredson, 2001). Schools appear to be adopting a dual strategy for preventing weapons in school: technology and peer reporting. Some schools have implemented safety technology such as video surveillance, others use physical surveillance programs such as security officers (Garcia, 2003), while others have metal detectors and bag searches (Juvonen, 2001). One of the common recommendations is for the schools to make available a means for other students to report when they know weapons are being brought on to school grounds (National Crime Prevention Council, 1995; Redden, 2000). Unfortunately, it is unclear how effective these efforts have been. In this article, we focus on one aspect of these efforts by examining the likelihood that students say they will report the presence of a weapon in their school. In addition, we examine the factors predictive of weapons reporting. 


\section{Students Who Will Report the Presence of Weapons}

No empirical research has addressed students' attitudes toward reporting weapons at school; however, several relevant criminological and developmental theories provide the groundwork for our hypotheses about student reporting. We focus on two major sources of theory: social bonding theory and a rational choice perspective on tattling or informing on others.

Two factors relevant to social bonding theory are examined. We consider whether exposure to deviant peers and connections to trusted adults differentially affect the likelihood of reporting. Social bonding theory suggests that delinquency results from weak or broken bonds to society and social structures (see Hirschi, 1969). Increased attachment to others, commitment to and involvement in conventional activities, and beliefs supportive of normative values all reduce the likelihood of delinquency. A logical extension is that social bonds increase the likelihood of reporting weapons in school. Deviant peers may increase the likelihood that a student knows of a weapon in school (e.g., Estell et al., 2003); however, association with deviant peers indicates weaker social bonding to conventional attachments (Erickson, Crosnoe, \& Dornbusch, 2000) and therefore reduces likelihood of reporting weapons to authorities. Conversely, students who report a relationship with a trusted adult in their family, school, or community would have greater attachment to others and therefore an increased likelihood of reporting.

In addition, research on tattling or reporting friends doing other activities would seem a promising source for a theoretical foundation of reporting on friends carrying weapons. The social costs of tattling appear to increase with age so that as children grow into adolescence, the social costs appear to be quite great (Greiger, Kauffman, \& Greiger, 1976; Lancellota \& Vaughn, 1989). Most of the work on tattling adopts a rational choice cost-benefit analysis to predict reporting behavior. The benefits are generally described as accruing to the larger unit (e.g., class, school, organization); however, the costs accrue to the individual informant in terms of social rejection (Friman et al., 2004). The developmental literature on "tattling" has a long but relatively sparse history as it relates to the social effects on adolescents (Friman et al., 2004). Nearly four decades ago, Stein, Sarbin, Chu, and Kulik (1967) asked high school-aged delinquent and nondelinquent boys to make moral judgments about different scenarios. A relevant outcome was their finding that delinquents more than nondelinquents rated informing on others as significantly more morally wrong. More recently, Friman et al. (2004) demonstrated that tattling did not win any friends among their sample of juveniles living in a residential care setting. The participants rated their tattling housemates as less likeable, and the socially rejected members were more often classified as the tattlers. These researchers found that even when the results of not reporting might be fatal, a general unwillingness to report on a peer is still present. In a study of suburban high school students, Kalafat and Elias (1992) found about one third of their sample had talked to a peer who was definitely considering suicide. Only $25 \%$ of those students reported that information to an adult.

Beyond adolescence, informing still carries social costs. Research examining police informants, or snitches, as they are often called, confirms the undesirability of a snitch (Rosenfeld, Jacobs, \& Wright, 2003). Snitching is usually defined as providing information in exchange for leniency or reward (Rosenfeld et al., 2003) and is said to be "the worst thing you can be" (from an interview with a street criminal, Rosenfeld et al., 2003, p. 298). Similarly, whistle-blowers who turn in fellow employees for corporate misconduct are viewed as disloyal to the company and their coworkers (MacNamara, 1991). In fact, loyalty to a 
friend was the primary factor cited by former U.S. Naval Academy cadets when considering informing on a fellow cadet (Pershing, 2002). Lawyers in general also appear to have a general aversion to turning in a fellow attorney for misbehavior (Toomey, 2004). Likewise, the police have a code of silence and are critical of those who do cross the blue line (Westmarland, 2005).

Do the social costs to friendship and likeability apply to reporting students who engage in potentially dangerous conduct such as carrying a weapon to school? Does the underlying negative notion of tattling that Friman et al. (2004) found carry over into public schools so that a student might be reluctant to report his or her knowledge of weapons? Finally, if policy makers are telling students to report their knowledge of weapons to an adult (National Crime Prevention Council, 1995) then we also need to know how comfortable students are with the adults they know. To these points, the current research focuses on the students' parents, adults from the students' school, and other adults in their community.

\section{Hypotheses}

Drawing from social bonding and rational choice theories, we begin by hypothesizing that students overall will be sensitive to the context, costs, and consequences of reporting. Specifically, we predict that students will be more likely to report (a) when their relationship to the target student is unspecified versus specified as friendship, (b) under conditions of anonymity rather than giving their name, and (c) when they do not perceive risk of physical or social consequences from the target student or the larger peer group. Next, we examine demographic factors as they relate to an overall willingness to report weapons. Rather than a specific set of hypotheses, we aim to provide a description of the type of student who is likely to report the presence of weapons. With this demographic description we focus on gender, age, grade in school, race, and school performance. To further describe students who are willing to report, we follow the demographic description with more detail about the students. First, we focus on the delinquency involvement (self and peers) of the students and the perceived involvement of adults (parents and other adults). It is predicted that students who have a higher level of self-reported delinquent involvement will be less likely to report when they know of the presence of weapons. In addition, students with a greater number of delinquent friends will also be less likely to report. Perceived involvement of adults is predicted to have the opposite effect. Specifically, we hypothesize that those students who report talking with their parents, have a caring adult in their life, and have an adult they can trust in their school will be more likely to report weapons than those students who do not perceive the presence of an adult in their lives. We will also explore a path model for weapons reporting and conduct comparisons between those students who say that they will always report and those who say that they would never report the presence of weapons.

\section{Method}

\section{Participants}

The current research was part of a larger project on middle-school youth violence. A total of 3,197 middle-school students from 27 schools in five states participated in the research by completing a self-report questionnaire. Five states in which project members had prior contacts with schools and that represented various geographic regions (e.g., North- 
east, South, West) were selected. Initial letters to school district representatives were followed with e-mail and phone calls. Ultimately, nine counties in the five states participated. A random subset of classes (excluding special education) was selected from the counties that agreed to participate. Students were eligible to participate if they had parental consent (see Procedures section below), provided active assent, and were themselves proficient English speakers.

For the analyses described in the sections that follow, students were excluded $(n=1204)$ if they had any missing values on demographic questions or questions concerning weapons reporting. For the remaining subscales, missing values were replaced by means if the student answered at least $80 \%$ of the questions in the subscale; otherwise the student was excluded. In addition, a small number of students $(n=36)$ with ages out of range for middle school (i.e., ages 10, 15, or 16 years) were removed. The final sample included 1,957 students. For those students who were not missing data on the demographic questions, comparison analyses revealed that overall removed participants were not statistically different in age or gender from those who were not removed; however, racial differences did emerge, $X^{2}(6, N=3015)=122.27, p<0.01$. Only $20 \%$ of the participants removed were White; however, $36 \%$ of the remaining participants were White. This discrepancy resulted from the differences for the African Americans and the Hispanic participants. Twenty-five percent of the removed participants were African American; however, only $17 \%$ of the remaining students were African American. Likewise, 38\% of those removed were Hispanics; however, only $29 \%$ of those remaining were Hispanic. Further comparison analysis revealed that students who remained in the data set reporting slightly better grades than those who were removed, $t(3088)=-9.4, p<0.01$ (remaining: $\mathrm{M}=6.34$, $\mathrm{SD}=1.80$; removed: $\mathrm{M}=5.75, \mathrm{SD}=1.64$; with a possible range of 1 to 8 ). Despite these differences, we felt it was important to exclude any participants who had missing data or were not of the appropriate age. Not only were we concerned about the integrity of one of our chosen statistical procedures (i.e., path analysis) if missing values were present, but also using this conservative approach suggests that we are more likely to be analyzing responses from students who were taking the survey seriously, felt comfortable answering the questions, and were representative of the average middle-school student.

Approximately $40 \%$ of the students in our remaining sample were from Florida, $26 \%$ from Connecticut, 14\% from California, 17\% from Texas, and 3\% from New Jersey. All of the original nine counties were still represented. The sample was evenly distributed across the three grades with $36 \%$ of the sample enrolled in sixth grade, $36 \%$ in seventh grade, and $28 \%$ in eighth grade. The students ranged in age from 11 to 14 years with the mean age of $12.61(\mathrm{SD}=0.94)$. Sixty-eight percent were either age 12 or 13 years. More girls $(62 \%)$ than boys (38\%) participated in our survey. The ethnic distribution of the sample was 37\% White, 29\% Hispanic, 16\% African American, 4\% Asian, 3\% Native American, 5\% multiracial, and $6 \%$ other. As compared to the national census values, our sample included a significantly smaller proportion of Whites, and more Hispanic youth. According to the U.S. Census (U.S. Dept. of Commerce, Bureau of the Census, 2003) there are approximately 63\% White youth between ages 11 and 14 years, 15\% African American, 15\% Hispanic, 3\% Asian, 2\% report being two or more races, and less than $1 \%$ American Indian and/or Alaskan Native or some other race. To allow for better statistical comparisons, Asian, Native American, multiracial, and other were collapsed together for this sample. Sixty-one percent of the sample reported receiving either mostly A's or mostly A's and B's in the preceding year. Only $11 \%$ reported mostly C's or below from their past year of school. 


\section{Materials}

As mentioned, the surveys were developed as part of a larger research project on youth violence that focused on personal and social characteristics underlying aggressive and other related behaviors. After piloting the initial measures and obtaining feedback from postassessment interviews, the final version of the questionnaire included 228 questions distributed across 14 different measures that elicited information about various topics related to youth aggression and related topics. For the purpose of the current research, however, only four main components are relevant (see Appendix for measures).

Demographics. Five questions assessed standard demographic characteristics. These asked about age, grade, gender, academic performance (grades), and race.

Willingness to report weapons. Developed specifically for this survey, these 10 questions ask respondents whether they would be willing to report a student who brought a weapon to school under a variety of circumstances. Four questions require students to respond yes or no to whether they would report a student and a friend, with and without anonymity being specified. The next six questions ask students to report their likelihood of reporting on a 4-point Likert-type scale with the options of "definitely would not report," "probably would not report," "probably would report," and "definitely would report" under various consequences to the weapon-carrying student and the student participant. In addition to individual analysis, the 10 questions were combined into one weapons reporting subscale score. The four dichotomous questions were summed to form a reporting summation score (range of 0 to 4). The six Likert-type scale (4-point scale) questions were averaged to form a reporting mean score (range of 1 to 4 ). These two components were summed to form a total weapons reporting score (WP Rept) that had a range from 1 to 8 with higher numbers indicating more willingness to report (Cronbach's a=0.85).

Relationship with adults. Twelve questions asked about the respondents' relationships with adults (parents or otherwise). Nine of these questions were a slightly modified form of the Presence of Caring-Individual Protective Factors Index (Phillips \& Springer, 1992). The original questions had the four answer choices of "YES!," "yes," "no," and "NO!" These were changed to Really True for Me, True for Me, Sort of True for Me, and Not True for $\mathrm{Me}$, respectively. In addition, questions during pilot testing led to a word change from assistance to help to make it clearer for the students answering the questionnaire (Cronbach's $a=0$.67). Developed specifically for the current study, the remaining three questions asked about the presence of an adult at the school whom the child could trust (yes or no), and how often the participant talked with parents about (a) how she or he is doing at school and (b) how things are going at school (Cronbach's $a=0.80)$. The final two questions were rated on a 5-point scale ranging from every day to never. All 12 questions are combined to make one measure of adult presence (Adult; Cronbach's $a=0.81$ ).

Self- and peer delinquency. Reduced versions of the Elliot Deviant Actions by Friends Scale (Peers; Cronbach's a=0.94) and a Self-Reported Delinquency Scale (SRDS; Cronbach's $\alpha=0.97)$ were employed to measure the delinquent behavior of the respondents' peers and their own general delinquent behaviors (Elliot, 1983). 


\section{Procedures}

Active caretaker consent was employed for obtaining participants. Two to three weeks prior to data collection, caretaker permission forms were sent to the school. In the schools with particularly high proportions of Hispanic students, the permission form was doublesided with one side written in English and the other side written in Spanish. Teachers distributed the permission letters for the students to take home and collected the completed forms when they were returned to school. The school was paid U.S. $\$ 2$ for each completed form. Forms were considered completed if they were signed and returned; it did not matter if the caretaker gave or denied permission to participate.

Data collection took place in a school auditorium, a cafeteria, a library, or a classroom. The researchers read a script at the start of each testing session that included information about the voluntary nature of the survey, and the students were told to skip any questions that made them feel uncomfortable or that for any reason they did not want to answer. The researchers also explained the anonymity of the survey and affirmed this by having the students turn in their complete (or incomplete) surveys to a box rather than directly to them. Students were not compensated for their participation.

Table 1

Conditions for Reporting

\begin{tabular}{|c|c|c|c|c|}
\hline \multicolumn{3}{|l|}{ Questions } & \multicolumn{2}{|c|}{ Answered Yes \% (n) } \\
\hline \multicolumn{3}{|c|}{$\begin{array}{l}\text { Would you report another student } \\
\text { who brought a knife, gun, or other } \\
\text { weapon to school? }\end{array}$} & \multicolumn{2}{|c|}{$70(1367)$} \\
\hline \multirow{2}{*}{\multicolumn{3}{|c|}{$\begin{array}{l}\text { so without giving your name? } \\
\text { Would you report it even if the stud } \\
\text { who carried the weapon was a frienc } \\
\text { of yours? }\end{array}$}} & \multicolumn{2}{|c|}{$83(1628)$} \\
\hline & & & \multicolumn{2}{|c|}{$58(1126)$} \\
\hline \multicolumn{3}{|c|}{$\begin{array}{l}\text { Would you report a friend if you could } \\
\text { do so without giving your name? }\end{array}$} & \multicolumn{2}{|c|}{$70(1368)$} \\
\hline & Definitely & Probably & Probably & Definitely \\
\hline & Would Not & Would Not & Would & Would \\
\hline & Report & Report & Report & Report \\
\hline $\begin{array}{l}\text { If the student who carried the } \\
\text { weapon might find out I told }\end{array}$ & $24(474)$ & $27(520)$ & $31(615)$ & $18(348)$ \\
\hline $\begin{array}{l}\text { If the student who carried the } \\
\text { weapon might hurt me }\end{array}$ & $26(501)$ & $17(326)$ & $19(377)$ & 38 (753) \\
\hline $\begin{array}{l}\text { If I believed that the student } \\
\text { who carried the weapon } \\
\text { would probably not use it }\end{array}$ & $18(352)$ & $28(557)$ & $29(564)$ & $25(484)$ \\
\hline $\begin{array}{l}\text { If people might think that I } \\
\text { am a snitch or tattle tale }\end{array}$ & $23(456)$ & $23(456)$ & $30(577)$ & $24(468)$ \\
\hline $\begin{array}{l}\text { If the student who carried the } \\
\text { weapon might get in trouble }\end{array}$ & 13 (257) & $17(335)$ & $36(702)$ & $34(663)$ \\
\hline $\begin{array}{l}\text { If the student who carried the } \\
\text { weapon might get arrested }\end{array}$ & $16(310)$ & $20(384)$ & $30(595)$ & $34(668)$ \\
\hline
\end{tabular}


The students were given 40 to 50 mins to complete the survey. The surveys were only provided in English. The decision was made not to translate the questionnaire into Spanish because the students who were participants were all attending public middle schools and were in regular classes (not English as a Second Language classes). In addition, research assistants maintained a list of questions that the students asked during the pilot phase of data collection. Every attempt was made to clarify the vocabulary of the original questions by changing the wording or by adding additional descriptive terms.

\section{Results}

\section{Conditions for Reporting}

Four questions asked about the likelihood of reporting and the likelihood of reporting if one could do so anonymously. For reporting generally and reporting anonymously, participants were asked separately about the likelihood of doing so if they were reporting "another student" or reporting a friend (see Table 1). Seventy percent of students remained consistent across both conditions; however, anonymity led $18.4 \%$ to change their response and report when they otherwise would not have, $X^{2}(1, N=1957)=296.74, p<0.01$. That pattern was similar when the weapon-carrying student was a friend. Fifty-eight percent said that they would report a friend, and $70 \%$ said that they would report a friend if they could do so without giving their name. Again, approximately $17.6 \%$ of students would report a friend under conditions of anonymity but not when conditions were unspecified, $X^{2}(1, N=1957)=553.18, p<0.01$.

To examine the effect of friendship, a chi-square also tested the effect of reporting a friend versus reporting generally when anonymity was not specified, $X^{2}(1, N=1957)=648.17, p<$ 0.01. Approximately $80 \%$ of students remained consistent across both circumstances $(26 \%$ not reporting, 53\% reporting a friend and generally). Sixteen percent would report generally but would not report a friend, and $4 \%$ indicated that they would not report generally but would report a friend.

The six additional weapons questions addressed reporting under circumstances specifying the perceived likelihood that the weapon would be used and the consequences of reporting to the reporter and the weapon carrier. Slightly more than one half of the students $(54 \%)$ indicated that they would definitely or probably report even if they believed that the student who carried the weapon probably would not use it. Concerns about the consequences of telling also appeared to influence some students. Approximately one half of the students said that they would definitely or probably report even if the student who carried the weapon might find out. Similarly, slightly more than $50 \%$ said they would definitely or probably report even if people might think they were a snitch or a tattletale. A belief that the weapon carrier might hurt them led more than one half $(58 \%)$ of the students to say they would definitely or probably report. Possible negative consequences for the weapon carriers led a majority to say they would report. Specifically, $70 \%$ of the students said that they would definitely or probably report if the student who carried the weapon might get in trouble, and $65 \%$ were willing to report if the student might get arrested (Table 1).

\section{Demographic Description of Those Who Will Report}

As mentioned above, the 10 individual weapons reporting questions were combined into one weapons reporting subscale score. This total weapon reporting score will be used in 
the analyses that follow. Overall, mean scores on the total weapon reporting score indicate that students were moderately willing to report weapons $(M=5.47, S D=1.98)$. In fact, only $3 \%(n=64)$ had the minimum score of 1 indicating that they would never report in any of the circumstances described.

An analysis of variance tested the independent variables of grade (sixth, seventh, eighth), gender, and race (African American, White, Hispanic, and other races) on the total weapon reporting score. Boys were somewhat less willing than females to report weapons $(\mathrm{M}=$ $5.21, \mathrm{SD}=2.13$ and $\mathrm{M}=5.60, \mathrm{SD}=1.88$, respectively), $F(1,1956)=13.40, p<0.01$. A significant main effect of race was found, $F(3,1953)=7.11, p<0.01$. Post hoc tests with Bonferroni correction indicated Hispanics $(M=5.17, S D=1.99)$ differed significantly from Whites $(\mathrm{M}=5.64, \mathrm{SD}=1.99)$ and Blacks $(\mathrm{M}=5.66, \mathrm{SD}=1.84)$, who did not differ from each other. The students in the collapsed Other race category $(M=5.44, S D=2.06)$ did not significantly differ from any other racial group. Likelihood of reporting also differed significantly by grade in school, $F(2,1954)=33.27, p<0.01$. Sixth graders were significantly more willing to report weapons $(M=5.90, S D=1.81)$ than eighth graders $(M=5.00, S D=2.10)$.

\section{Table 2}

Demographic Description for Willingness to Report

\begin{tabular}{lcc}
\hline Attributes & M (SD) & Statistic \\
Males & $5.26(2.13)$ & $F=13.40^{*}$ \\
Female & $5.60(1.88)$ & \\
African American & $5.66(1.84)$ & $F=7.11^{*}$ \\
Hispanic & $5.17(1.99)$ & \\
White & $5.64(1.98)$ & $F=3.27^{*}$ \\
Other & $5.44(2.06)$ & \\
Sixth grade & $5.90(1.81)$ & \\
Seventh grade & $5.41(1.97)$ & \\
Eighth grade & $5.01(2.10)$ & \\
\hline Correlations & & Willingness to Report \\
Variables & & $0.19^{*}$ \\
Age & & \\
Grades & & \\
${ }^{*} p<0.01$. & & \\
\hline
\end{tabular}

Table 3

Influence of Adult and Delinquent Involvement in Relation to Reporting

\begin{tabular}{lcc}
\hline Attributes & M (SD) & Statistic \\
Adult at school can trust & $5.87(1.76)$ & $t=-15.63^{*}$ \\
No adult at school can trust & $4.36(2.17)$ & \\
\hline Correlations & & \\
\hline Variables & Willingness to Report \\
Caring adult & $0.30^{*}$ \\
Talking with parents & $0.32^{*}$ \\
Self-Reported Delinquency Scale & $-0.44^{*}$ \\
Delinquent peers & $-0.45^{*}$ \\
\hline
\end{tabular}
${ }^{*} p<0.01$. 
Seventh graders $(\mathrm{M}=5.41, \mathrm{SD}=1.97)$ were significantly different from both. Similarly, as age increased, willingness to report decreased resulting in a weak, but significant negative correlation, $r(1955)=-0.19$. A weak significantly positive correlation was present between grades received and willingness to report weapons, $r(1955)=0.18, p<0.01$. The higher the reported grades, the more youth indicated their willingness to report. The aforementioned comparisons are also shown in Table 2.

\section{Delinquency and Perceived Adult Involvement for Those Willing to Report}

Overall, students in our sample reported relatively high trust and involvement levels for adults in their lives (Table 3). Approximately three fourths of our sample said that they had an adult at their school they could trust (74\%). Similarly, close to two thirds said that they talked to their parents 2 times per week or more about how they are doing in school $(63.3 \%)$ and about things that happened at school (59.4\%). The students also reported relatively high scores on the Caring Adult scale $(M=29.50, S D=5.5$; with a possible range from 9 to 36).

Based on our hypothesis that students who had more of an adult presence in their lives would be more willing to report, we employed the same willingness to report total score as above in conjunction with the questions about adults. Students who indicated that they had an adult at their school whom they trusted had higher scores on the reporting total score than those who did not have an adult they could trust $(\mathrm{M}=5.87, \mathrm{SD}=1.76$ and $\mathrm{M}=$ $4.36, \mathrm{SD}=2.17$, respectively) $t(1955)=-15.63, p<0.01$. Likewise, there was a significant positive correlation between the Caring Adult score and the willingness to report weapons, $r(1955)=0.30, p<0.01$, and between the talking with parents score and willingness to report, $r(1955)=0.32, p<0.01$.

The students in our sample had fairly low self-reported delinquency scores. These low scores would be expected because our sample was from standard classrooms in nonspecialized schools and involved selection bias for the students who are traditionally more likely to take home and return a permission form. These factors likely contributed to the overall low rate of self-reported delinquency. On a scale from 1 to 5, with a higher score indicating more delinquency, our sample had a mean barely over the minimum score $(\mathrm{M}=$ $1.49, \mathrm{SD}=0.68)$. Similar results emerged for friends' delinquent behaviors. Again, the scale was from 1 to 5 with higher values indicating more friends who had participated in delinquent behaviors. Our sample had an overall low average $(\mathrm{M}=1.69, \mathrm{SD}=0.75)$.

Even with the low self-reported delinquency rates, a significant negative correlationwas present between the students' own delinquency and their willingness to report $r(1955)=$ $-0.44, p<0.01$. Likewise, students who had more friends who were participating in delinquent activities were less willing to report if another student brought a weapon to school $r(1955)=-0.45, p<0.01$.

Path Model for Willingness to Report

A path analysis was computed with maximum likelihood estimation in LISREL 8.7 (Jöreskog \& Sörbom, 2004). The hypothesized path model is presented in Figure 1 with the rectangles representing the observed variables based on the subscales from the questionnaire. The model was fit by borrowing a theoretical foundation from the literatures on delinquency, informing, and social bonding. For the current model, we hypothesized that the demographic characteristics would predict weapons reporting, mediated by peer de- 
linquency. The presence of adults would predict weapons reporting directly. The importance of peer delinquency is highlighted and, therefore, included as a mediating variable because the literature on students who report bringing weapons to school suggests that carrying a weapon is usually not the only deviant behavior of a youth (Bailey et al., 1997; Estell et al., 2003; Malek et al., 1994). Therefore, those students who report higher levels of

Figure 1

Path Diagram for Willingness to Report Weapons With Standardized Estimates

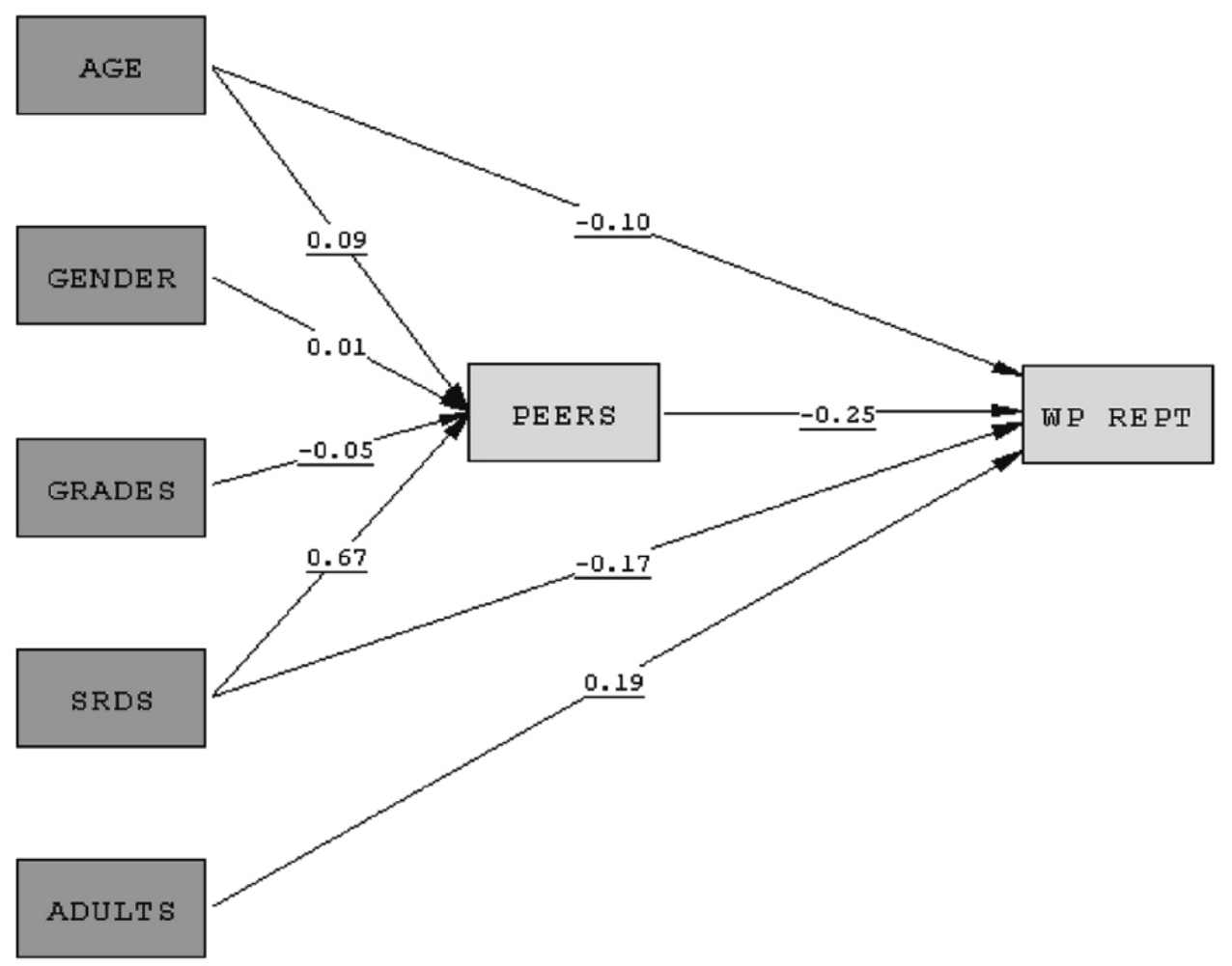

Note: $X^{2}=45.02 ; d f=13 ; p=0.00002 ;$ root mean square error of approximation (RMSEA) $=0.036 ; \mathrm{WP}$ Rept $=$ total weapons reporting score; SRDS $=$ Self-Reported Delinquency Scale.

peer delinquency will also likely be the ones who know more students who carry weapons to school and who have the weaker social bonds with conventional attachments. In the figure, the absence of a line between variables means that there was no hypothesized direct effect. The testing of the model is traditionally done by employing three criteria: global fit measures, individual parameter significance testing, and testing of the magnitude and direction of parameter estimation (Schumacker \& Lomax, 2004). These three criteria are outlined below for the current model.

The global model fit was tested using a chi-square goodness of fit and the RMSEA. The chi-square statistic is based on a comparison between the sample covariance matrix and the estimated population covariance matrix (Schumacker \& Lomax, 2004). Because the 
goal is to develop a model that fits the data, a nonsignificant chi-square is desired; however, the chi-square value can be highly influenced by the sample size (Schumacker \& Lomax, 2004; Ullman, 1996). Even fairly minor differences can lead to significant chi-square values when a large sample size is used. For the current analyses, the chi-square indicated a lack of fit, $0.2(13, N=1,957)=45.02, p<0.01$; however, this may have been the result of the extremely large sample size. For the RMSEA, Browne and Cudeck (1993) recommended that scores should be at .08 or below to indicate a good fitting model. Others advise a standard of less than 0.05 (Schumacker \& Lomax, 2004). Employing either of these assessment values, the current model appears to have a good fit with RMSEA $=0.036$.

An area of much research debate has resulted in researchers developing a number of fit indices that enable an assessment of the model while eliminating or minimizing the effect of the large sample size (Ullman, 1996). For instance, the Non-Normed Fit Index (NNFI) compares the 0.2 value of the model to the 0.2 value of the independence model while also incorporating the degrees of freedom. The values then range from 0 to 1 with values over 0.90 considered indicative of a good-fitting model (Ullman, 1996). For the current model the NNFI $=0.99$, indicating a good fitting model. Likewise, the Adjusted Goodness-ofFit Index (AGFI) is based on the weighted proportion of variance in the sample covariance matrix accounted for by the estimated population covariance matrix while also taking into account the number of parameters estimated in the model (Ullman, 1996). A 0 indicates no fit while a 1 indicates a perfect fit. AGFI values close to .95 are considered representative of a good-fitting model (Schumacker \& Lomax, 2004). For the current model, this fit index also confirmed a good fit for the model (AGFI $=0.99$ ).

Indices are also available that are based on the residuals. The root mean square residual (RMR) and the standardized root mean square residual (SRMR) represent the difference between the sample variance and covariance and that of the estimated population variance and covariance (Ullman, 1996). Although the RMR must be interpreted in light of the scale employed, the SRMR is standardized and has a range from 0 to 1 , with smaller values indicating a better fit, and a SRMR of 0 indicating a perfect fit of the model. Kline (1998) reported that SRMR values should be 0.10 or less to indicate adequate fit; however, others have suggested that less than 0.05 is desired (Ullman). Using either standard, our current model appears to have a good fit $($ SRMR $=0.019)$.

For individual characteristics, the standardized coefficients are presented on the path diagram. Significant paths have underlined standardized values. Based on the t values, only the path from gender going into the delinquent peers measure was not significant. All of the paths were in the expected direction with older youth and higher scores on self-reported delinquency having greater scores on peer delinquency. Lower reported grades were related to higher levels of peer delinquency. All path coefficients into weapons reporting were negative except the combined adult variable. Older adolescents, those with more delinquent peers, and those with higher rates of self-reported delinquency had less willingness to report the presence of weapons. Those with higher adult scores expressed a greater willingness to report weapons. The characteristics that appeared to be the most influential in predicting students' willingness to report were their own delinquent behavior and the delinquent behavior of their friends.

\section{Students Who Will Always and Those Who Will Never Report}

Only 64 students $(3.3 \%)$ said that they would never report (answered no to all four reporting questions and answered definitely not report to all six scaled questions). Similarly, 
Table 4

Descriptive Comparisons between Students Who Said That They Would Always Report and Those Who Said They Would Never Report

\begin{tabular}{|c|c|c|c|c|c|}
\hline \multirow[b]{2}{*}{ Variable (Range) } & \multicolumn{2}{|c|}{$\begin{array}{l}\text { Never Report } \\
(n=64)\end{array}$} & \multicolumn{3}{|c|}{$\begin{array}{l}\text { Always Report } \\
(n=93)\end{array}$} \\
\hline & $\mathrm{M}$ & SD & $\mathrm{M}$ & SD & $\bar{t}$ \\
\hline Age (11-14) & 12.98 & 0.83 & 12.31 & 0.91 & $4.73^{*}$ \\
\hline Grades $(1-8)+$ & 5.5 & 2.25 & 6.4 & 1.88 & $-2.70^{*}$ \\
\hline Self-Reported Delinquency & 2.48 & 1.3 & 1.23 & 0.47 & 7.37 \\
\hline \multicolumn{6}{|l|}{ Scale $(1-5)$} \\
\hline Caring adult (1-9) & 25.42 & 6.64 & 29.69 & 5.97 & $-4.21^{*}$ \\
\hline Talking to parents (2-10) & 5.34 & 2.91 & 8.06 & 2.63 & $-6.10^{*}$ \\
\hline \multirow{2}{*}{ Delinquent peers $(1-5)$} & 2.79 & 1.24 & 1.29 & 0.45 & $9.26^{*}$ \\
\hline & \multicolumn{2}{|c|}{ Never Report } & \multicolumn{3}{|c|}{ Always Report } \\
\hline Variable & $\%$ & $(n)$ & $\%$ & $(n)$ & $X^{2}$ \\
\hline Male & 46 & (36) & 54 & $(43)$ & 1.52 \\
\hline Female & 36 & (28) & 64 & (50) & \\
\hline $\begin{array}{l}\text { No adults at school } \\
\text { can trust }\end{array}$ & 73 & $(46)$ & 27 & (17) & $45.33^{*}$ \\
\hline $\begin{array}{l}\text { Adult at school } \\
\text { can trust }\end{array}$ & 19 & $(18)$ & 81 & $(76)$ & \\
\hline Sixth grader & 23 & (14) & 77 & $(48)$ & $16.03^{*}$ \\
\hline Seventh grader & 46 & (24) & 54 & (28) & \\
\hline Eighth grader & 60.5 & (26) & 39.5 & (18) & \\
\hline African American & 20 & (5) & 80 & (20) & $7.58^{*}$ \\
\hline Hispanic & 54 & (19) & 46 & (16) & \\
\hline White & 39 & (24) & 61 & (38) & \\
\hline Other & 46 & (16) & 54 & (19) & \\
\hline
\end{tabular}

${ }^{*} p<0.01 ;+$ higher scores indicate better grades.

only $93(4.8 \%)$ students reported that they would always report. Although a very small proportion of the current sample, comparisons between these two groups revealed significant differences in all of the expected directions. Students who said that they would always report were younger, reported getting higher grades, had lower self-reported delinquency scores, had lower scores on the peer delinquency scale, reported talking with their parents more, and reported higher scores on the Caring Adult scale (Table 4). Chisquare analysis revealed that always reporting versus never reporting appears to be independent of gender but dependent on race and grade in school (Table 4). African American students indicated that they would "always report" at a much higher rate than statistically expected. Of the African American students who said that they would either always report or never report $80 \%(n=20)$ said that they would always report (Adjusted Residual $=2.3$ ). None of the other racial groups had observed scores significantly different from the expected scores based on the adjusted residual comparison score of 2. For grade in school, significantly more sixth graders said that they would always report (Adjusted Residual = 3.7), and significantly fewer eighth graders said that they would always report (Adjusted Residual $=-3.1$ ). 


\section{Discussion}

This is the first attempt to determine what factors, either internal or external to the respondent, might influence students' willingness to report their knowledge of weapons in their school. Despite the limitations of self-report data, the conditions of reporting and some demographic characteristics appear to make a difference. In fact, significant differences do emerge between those students who are more willing to report and those who are less willing. Previous research demonstrated that informing about a peer's behavior is not regarded very highly (Friman et al., 2004; Pershing, 2002; Rosenfeld et al., 2003; Stein et al., 1967). The current research partially confirms this notion; however, a great majority of students indicated that if they were given the chance, they would report the presence of a weapon in their school. Very few students in the sample said that they would always report if they knew of the presence of a weapon. In the same way, very few students indicated they would never report. The students' answers indicated that some of the measured and theoretically predicted factors influenced their willingness to report.

It is important to note the effect of anonymity on reporting for the youth in the current sample. As school officials and policy makers decide how to address weapons on school grounds, they should recognize the need for an anonymous reporting system. For many of the students, being able to anonymously report would make a positive difference in their decision to report a friend or classmate. A majority of the students in our sample said that they would report a student who carried a weapon; however, the proportion increased if the option of reporting anonymously was provided. This pattern was also present when the weapon carrier was described as a friend. In addition, concerns about the weapon carrier finding out that the reporting student told created some concern among our sample. The students appeared to make judgments about the likelihood that the weapon would get used, and their decision to report was based on that judgment. The students indicated that fear of retaliation from the weapon carrier and from peers would also have an effect on their decision to report.

In addition to the conditions of reporting, demographic factors appeared to influence the decision to report. For instance, males were slightly less willing to report than females. Racial differences in reporting were most pronounced between African American and Hispanic youth; however, this difference was minor. Willingness to report decreased as the students got older and closer to moving from middle school to high school. The students who made better grades appeared more willing to report than the students who struggled more academically. Beyond the simple demographic characteristics, it seems clear that factors such as peer group, own delinquency, and involvement of adults were all factors related to a student's willingness to report. Especially pronounced is the presence of an adult at the school the students believe they can trust.

Those students who are unlikely to report the presence of a weapon in their school are quite similar to the students who carry weapons to school. Previous research has demonstrated that males (May, 1999), those with poor parent-adult relationships (Bailey et al., 1997; Orpinas et al., 1999), those who are delinquent (Brown, 2004), and those who have delinquent peers (Rountree, 2000) will be more likely to carry a weapon. Similarly, those students who have more delinquent friends were found to be less likely to report if they knew of weapons. This creates a disappointing cycle with students who have more delinquent friends being less likely to report weapons. Because carrying a weapon is related to other delinquent activities (Bailey et al., 1997; Estel et al., 2003; Malek et al., 1998), those students who are most likely to carry weapons to school are also the students who have friends who are the least likely to report them. 
Although the current research does attempt to provide insight into a student's willingness to report weapons, several limitations must be noted. The sample for the current study is clearly not representative of the entire population of middle-school students. Nonprobability sampling techniques were employed, and oversampling of certain racial groups took place. Possibly most important is the exclusion of students who have more pronounced delinquent backgrounds. The current sample did not include a large number of delinquent youth or youth with delinquent friends. Future research should examine responses from a more delinquent sample because evidence suggests that the delinquent youth will be the ones who have more opportunities to know someone who carries a weapon to school (Bailey et al., 1997; Estell et al., 2003; Malek et al., 1998) yet the least likely to report.

Cautions should also be noted concerning the path analysis. Although current practice is moving toward testing several models and making modifications based on a combination of statistical testing and theoretical mapping, we stopped with only one model. In addition to having a good fitting model already, we wanted to be cautious with attempts to draw too much from the path analysis. As noted by some researchers (Ullman, 1996), path analysis must be carefully conducted and based on strong theoretical foundations. This was a first attempt at studying factors that might influence weapons reporting, and a nonprobability sample was employed. To take this path analysis further would only invite theoretical explanation that would be arguably based on post hoc speculation.

Despite the limitations, however, it is clear that the current data suggest the need for healthy relationships between middle-school youth and adults. Students who knew they had an adult they could trust or who talked to their parents on a regular basis were more likely to report the presence of weapons. Telling students that they must report their friends or classmates undoubtedly feels like an empty requirement if the student has no one to tell. Based on the current findings, students would likely also favor a system allowing for anonymous reporting. It is unclear from these data if an anonymous system alone would be sufficient or if the need for a trustworthy and caring adult would still be relevant.

\section{Conclusion}

Although a relatively minor proportion of violence that occurs at schools involves weapons, the consequences of such events have the potential to be quite devastating. In addition, students, parents, and policy makers have substantial anxiety concerning such events. With this increased fear that violent acts will take place at school, schools are implementing a number of strategies. Security technologies are generally quite expensive (Garcia, 2003); however, students reporting when they believe someone has a weapon may be a more cost-effective approach. This strategy places classmates and friends on the offensive against weapons in schools. The current research revealed that students do feel a sense of loyalty to their classmates and friends. That loyalty might be born out of fear of retaliation or purely from the natural human notion that to "snitch" on someone is somehow wrong. Either way, students are less reluctant to inform on their friends and classmates when it can be done anonymously. The reluctance is magnified when the potential informer is involved in delinquent behaviors. Nonetheless, the students in the current sample indicated that they needed an adult whom they could trust to feel that they could report the presence of weapons. Clearly, the students who talked to their parents, had some adult they could trust, or had some adult who cared about them were more willing to report the presence of weapons. 
Anecdotally we already knew that the relationship between an adult and a possible informer can indeed make a difference. Recall the earlier mentioned aborted plans of Andrew Osantowski, the youth whose plans at massive school violence were reported by a fellow-chat room visitor. He gave a chilling statement in one of his online messages. He said, "NOW I DON'T CARE IF THEIR [sic] ARE 500 POLICE around school... because if someone is determined enough to do something they will do it... put all the security measures you ever want in there ... it doesnt [sic] matter...if someone wants to do something, they will do it...itdoesnt [sic] matter" (Manolatos \& Cardenas, 2004). Contrary to what Osantowski believed, his plans were changed when another youth reported to a parent and that parent acted on the threats. Clearly, Osantowski is just one youth and we certainly cannot draw general conclusions from the result in his situation; however, his case does provide an account of what might happen if other children are willing to report when they know about the presence of weapons.

\section{Appendix}

Questions from Survey

The instructions are presented immediately before the questions. The question set labels are provided here for reference but were not included in the actual questionnaire.

Demographic Characteristics

Grade: Sixth Seventh Eighth

$\begin{array}{llllllll}\text { Age: } & 10 & 11 & 12 & 13 & 14 & 15 & 16\end{array}$

Sex: $\quad$ Male Female

What grades did you get on your most recent report card?

$\begin{array}{lll}\text { Mostly As } & \text { Mostly Ds } & \text { Mostly Cs and Ds } \\ \text { Mostly Cs } & \text { Mostly As and Bs } & \text { Mostly Ds and Fs }\end{array}$

Mostly Cs Mostly Bs and Cs

RACE: Please mark one of the numbers below that goes with the choice that matches how you would describe your race.

1. Asian or Asian American, including Chinese, Japanese, Indian, and/or others

2. Black or African American

3. Hispanic or Latino(a), including Cuban American, Central American (such as Mexican American), South American, and/or others

4. White, Caucasian, Anglo, or European American; not Hispanic

5. American Indian/Native American

6. Multiracial, more than one race or ethnic group

7. Other (please list) 
Appendix (continued)

Weapons Reporting Questions

For the next few questions please answer Yes or No to indicate what you would do or how you feel.

Would you report another student who brought a knife, gun, or other weapon to school? Yes No

Would you report it if you could do so without giving your name? Yes No

Would you report it even if the student who carried the weapon was a friend of yours? Yes No

Would you report a friend if you could do so without giving your name? Yes No

Some students might be more or less likely to report another student who brought a knife, gun, or other weapon to school. For each of the situations listed below, rate how likely you would be to report.

\begin{tabular}{|c|c|c|c|c|}
\hline & $\begin{array}{l}\text { Definitely Would } \\
\text { Not Report }\end{array}$ & $\begin{array}{l}\text { Probably Would } \\
\text { Not Report }\end{array}$ & $\begin{array}{l}\text { Probably } \\
\text { Would Report }\end{array}$ & $\begin{array}{l}\text { Definitely } \\
\text { Would Report }\end{array}$ \\
\hline $\begin{array}{l}\text { If the student who carried the } \\
\text { weapon might find out I told }\end{array}$ & 1 & 2 & 3 & 4 \\
\hline $\begin{array}{l}\text { If the student who carried } \\
\text { the weapon might hurt me }\end{array}$ & 1 & 2 & 3 & 4 \\
\hline $\begin{array}{l}\text { If I believed that the student } \\
\text { who carried the weapon would } \\
\text { probably not use it }\end{array}$ & $d$ & 2 & 3 & 4 \\
\hline $\begin{array}{l}\text { If people might think that } \\
\text { I am a snitch or tattle tale }\end{array}$ & 1 & 2 & 3 & 4 \\
\hline $\begin{array}{l}\text { If the student who carried the } \\
\text { weapon might get in trouble }\end{array}$ & 1 & 2 & 3 & 4 \\
\hline $\begin{array}{l}\text { If the student who carried } \\
\text { the weapon might get arrested }\end{array}$ & 1 & 2 & 3 & 4 \\
\hline
\end{tabular}

Talking With Parents Questions

For the following items, choose a number from (1) for Every Day to (5) for Never that best describes how often you talk with your parents about these things. Mark the number you choose.

\begin{tabular}{lcccc} 
Every Day & $\begin{array}{l}2 \text { or 3 Times } \\
\text { a Week }\end{array}$ & $\begin{array}{c}\text { Once Once } \\
\text { a Week a Month }\end{array}$ & \multicolumn{2}{c}{ Never } \\
How often do you talk with your 1 & 2 & 3 & 4 & 5 \\
parents about how you are doing in school? & & 3 & 4 & 5
\end{tabular}

parents about things that happen at school?

Note: Original scores were reverse coded and then the two questions were summed. Low scores indicated less talking and high scores indicated more talking.

Adult Trust Question

For the next few questions please answer Yes or No to indicate what you would do or how you feel (this question was part of a set of questions).

Do you trust any adults at your school? Yes No 


\section{References}

Bailey, S.L., R.L. Flewelling and D.P. Rosenbaum (1997). Characteristics of students who bring weapons to school. Journal of Adolescent Health 20: 261-270.

Bauer, S. (2003, March 2). Weapons in school: fewer cases reported. News Gazette. Retrieved July 26, 2004, from www.news-gazette.com http://www.news-gazette.com/news/local/2003/03/02/weapons_in_school_fewer_cases_reported.

Brooke, J. (1999, May 11). Teacher of Colorado gunmen alerted parents. New York Times, p. A14.

Brown, B. (2004). Juveniles and weapons: recent research, conceptual considerations, and programmatic interventions. Youth Violence and Juvenile Justice: An Interdisciplinary Journal 2: 161-184.

Browne, M.W. and R. Cudeck (1993). Alternative ways of assessing model fit. In: K.A. Bollen and J.S. Long (editors), Testing Structural Equation Models (pp. 136-162). Newbury Park, Calif.: Sage.

Corvo, K., and K. Williams (2000). Substance abuse, parenting styles, and aggression: An exploratory study of weapon carrying students. Journal of Alcohol and Drug Education, 46, 1-13.

Crittenden, J. (1999, April 25). High school horror: hate filled diary shows "big kill" was well-planned. Boston Herald, p. 004.

DeVoe, J.F., K. Peter, P. Kaufman, A. Miller, M. Noonan, T.D. Snyder, et al. (2004, November). Indicators of School Crime and Safety: 2004 (NCES 2005-002 NCJ 205290). Washington, D.C.: U.S. Government Printing Office.

Elliott, D.S. (1983). National Youth Survey, Wave VI. Ann Arbor, Mich.: Inter-University Consortium for Political and Social Research.

Erickson, K.G., R. Crosnoe and S.M. Dornbusch (2000). A social process model of adolescent deviance: combining social control and differential association perspectives. Journal of Youth and Adolescence 29: 395-425.

Estell, D.B., T.W. Farmer, B.D. Cairns and J.T. Clemmer (2003). Self-report weapon possession in school and patterns of early adolescent adjustment in rural African American youth. Journal of Clinical Child and Adolescent Psychology 32: 442-452.

Forrest, K.Y.-Z., A.K. Zychowski, W.L. Stuhldreher and W.J. Ryan (2000). Weapon-carrying in school: prevalence and association with other violent behaviors. American Journal of Health Studies 16: 133-140.

Friman, P.C., D.W. Woods, K.A. Freeman, R. Gilman, M. Short, A.M. McGrath, et al. (2004). Relationship between tattling, likeability, and social classification. Behavior Modification 28: 331-348.

Garcia, C. A. (2003). School safety technology in America: Current use and perceived effectiveness. Criminal Justice Policy Review 14: 30-54.

Glaberson, W. (1999, April 27). Case against parents would be hard to prove. New York Times, p. A20.

Gottfredson, G.D., and D.C. Gottfredson (2001). What schools do to prevent problem behavior and promote safe environments. Journal of Educational and Psychological Consultation 12: 313-344.

Grieger, T., J.M. Kauffman and R.M. Grieger (1976). Effects of peer reporting on cooperative play and aggression of kindergarten children. Journal of School Psychology 14: 307313. 
Hirschi, T. (1969). Causes of Delinquency. Berkeley, Calif.: University of California Press. Jöreskog, K., and D. Sörbom (2004). LISREL 8.71 student edition [Computer software]. Lincolnwood, Ill.: Scientific Software International.

Juvonen, J. (2001). School Violence: Prevalence, Fears, and Prevention. Retrieved November 10, 2004, from http://www.rand.org/publications/IP/IP219.

Kalafat, J., and M. Elias (1992). Adolescents' experience with and response to suicidal peers. Suicide and Life-Threatening Behavior 22: 315-321.

Kline, R.B. (1998). Principles and Practice of Structural Equation Modeling. New York: Guilford.

Lancelotta, G., and S. Vaughn (1989). Relation between types of aggression and sociometric status: peer and teacher perceptions. Journal of Educational Psychology 81: 86-90.

MacNamara, D.E.J. (1991). The victimization of whistle-blowers in the public and private sectors. In: R.J. Kelly and D.E.J. MacNamara (editors), Perspectives on Deviance: Dominance, Degradation, and Denigration (pp. 121-134). Cincinnati, Ohio: Anderson.

Malecki, C.K., and M.K. Demaray (2003). Carrying a weapon to school and perceptions of social support in an urban middle school. Journal of Emotional and Behavioral Disorders 11: 169-178.

Malek, M. K., Chang, B.-H., \& Davis, T. C. (1998). Fighting and weapon-carrying among seventh-grade students in Massachusetts and Louisiana. Journal of Adolescent Health 2: 94102.

Manolatos, T., and E.L. Cardenas (2004). Clinton teen rages, threatens on Internet. Detroit News. Retrieved September 23, 2004, from http:/ / www.detnews.com.

Martin, S.L., L.S. Sadowski, N.U. Cotton and D.R. McCarraher (1996). Response of African-American adolescents in North Carolina to gun carrying by school mates. Journal of School Health 66: 23-26.

May, D.C. (1999). Scared kids, unattached kids, or peer pressure: why do students carry firearms to school? Youth \& Society 13: 100-127.

National Crime Prevention Council. (1995). Strategy: School Crime Reporting Hotline. Retrieved July 26, 2004, from http://www.ncpc.org/Topics/School_Safety/Strategy_ School_Crime_Reporting_Hotline.php.

National League of Cities. (1998). School Violence in America's Cities. Washington, D.C.: Author.

Olinger, D., and P. Lowe (1999, October 18). Parents try to cope with killers' legacy: pain of own loss, others' lingers after Columbine. Denver Post, p. A01.

Orpinas, P., N. Murray and S. Kelder (1999). Parental influences on students' aggressive behaviors and weapon carrying. Health Education \& Behavior 26: 775-787.

Pershing, J.L. (2002). Whom to betray? Self-regulation of occupational misconduct at the United States Naval Academy. Deviant Behavior 23: 149-175.

Phillips, J., and F. Springer (1992). Extended National Youth Sports Program 1991-1992 evaluation highlights, part two: Individual Protective Factors Index and risk assessment study. In: L.L. Dahlberg, S.B. Toal and C.B. Behrens (editors), Measuring Violence-Related Attitudes, Beliefs, and Behaviors among Youth: A Compendium of Assessment Tools (1998). Atlanta, Ga.: Centers for Disease Control and Prevention.

Police: Teen foils bomb plot. (2004). CNN.com. Retrieved September 27, 2004, from http:/ / www.cnn.com/2004/LAW/09/20/internet.threats.ap/index.html.

Possessing or Discharging Weapons or Firearms at a School-Sponsored Event or on School Property Prohibited; Penalties; Exceptions, Fla. Stat. \$790.115 (2004). 
Redden, J. (2000). Snitch Culture: How Citizens Are Turned into the Eyes and Ears of the State. Venice, Calif.: Feral House.

Rosenfeld, R., B.A. Jacobs and R. Wright (2003). Snitching and the code of the street. British Journal of Criminology 43: 291-309.

Rountree, P.W. (2000). Weapons at school: are the predictors generalizable across context? Sociological Spectrum, 20, 291-324.

San Diego City Schools. (2004). "A dozen things principals can do to stop school violence." Retrieved July 26, 2004, from http:/ / www.sdcs.k12.ca.us/comm/factsheets/.

Savastana, M.A. (2003). Tattle-telling on the United States: school violence and the international blame game. Pennsylvania State International Law Review 21: 649-668.

Schumacker, R.E., and R.G. Lomax (2004). A beginner's guide to structural equation modeling (2nd ed.). Mahwah, N.J.: Lawrence Erlbaum.

Stein, K.B., T.R. Sarbin, C.-L. Chu and J.A. Kulik (1967). Adolescent morality: its differentiated structure and relation to delinquent conduct. Multivariate Behavioral Research 2: 199210.

Sullivan, J. (2002). "School house hype: two years later." Center on Juvenile and Criminal Justice Executive Summary. Retrieved October 7, 2004, from http://www.cjcj.org/pubs/ schoolhouse/shh2exec.html.

Toomey, K.A. (2004). Practice pointer: the snitch rule. Utah State Bar 17: 24-26.

Ullman, J.B. (1996). Structural equation modeling. In: B.G. Tabachnick and L.S. Fidell (editors), Using Multivariate Statistics (3rd ed., pp. 709-811). New York: HarperCollins.

U.S. Department of Commerce, Bureau of the Census. (2003). Census of population and housing, 2000: Summary file 4. Washington, DC: Author.

Westmarland, L. (2005). Police ethics and integrity: breaking the blue code of silence. Policing and Society 15: 145-165.

Wilcox, P., and R.R. Clayton (2001). A multilevel analysis of school-based weapon possession. Justice Quarterly 18: 509-541.

Eve M. Brank is an assistant professor in the Department of Criminology, Law and Society at the University of Florida in Gainesville, Florida. Her research focuses primarily on families, juveniles, and especially parental responsibility laws. She has been at the University of Nebraska-Lincoln in the Department of Psychology since 2009.

Jennifer L. Woolard is an assistant professor of psychology at Georgetown University in Washington, D.C. Her research focuses on adolescent development in family and legal contexts, particularly on police interrogation and court procedures.

Veda E. Brown is an assistant professor of psychology at Prairie View A\&M University in Texas. Her research areas include cognitive development in early childhood especially with reference to role of parents. She has also conducted extensive research to uncover factors associated with violent and/or aggressive behavior patterns in middle-school students and the role of parents in mediating such behaviors.

Mark Fondacaro is a professor of psychology at John Jay College of Criminal Justice. He received his PhD in clinical psychology from Indiana University and his JD from Columbia University School of Law. His major research interests are ecological jurisprudence and the conceptualization and assessment of procedural justice in legal and extralegal contexts. 
Jennifer L. Luescher is a staff psychologist at Bridgewater State Hospital in Bridgewater, Massachusetts.

Ramona G. Chinn is an assistant professor at the University of Hawaii School of Nursing. She teaches primarily in the graduate program in child and adolescent mental health. Her research focuses on resiliency factors as well as gender and ethnic disparities in children's mental health.

Scott A. Miller is a professor in the Department of Psychology at the University of Florida in Gainesville, Florida. His research areas include cognitive development in children and parents' beliefs about children. 